\title{
Impacts of Top Five Executives' Compensation on Employee Wages
}

\author{
Qianqian $\mathrm{Li}^{1} \&$ Unyong Pyo ${ }^{2}$ \\ ${ }^{1}$ EA of Director of English Language Center, Xi'an Jiaotong-Liverpool University (XJTLU), Suzhou, China \\ ${ }^{2}$ Department of Finance, Operations, and Information Systems (FOIS), Goodman School of Business, Brock \\ University, St. Catharines, Canada \\ Correspondence: Unyong Pyo, Associate Professor of Finance, Department of Finance, Operations, and Information \\ Systems (FOIS), Goodman School of Business, Brock University, St. Catharines, ON, Canada, L2S3A1. Tel: \\ 905-688-5550, x3147. E-mail: upyo@brocku.ca
}

Received: September 19, 2020

Accepted: November 4, 2020

Online Published: January 1, 2021

doi:10.5430/ijfr.v12n1p242

URL: https://doi.org/10.5430/ijfr.v12n1p242

\begin{abstract}
This paper studies the impacts of incentive compensation to top five executives on employee wages. We employ pay-performance sensitivity to measure executive incentive compensation. Using the sample during $1992-2017$, we find that executive compensation has negative impacts on employee wages. In addition, we examine the impacts of executive incentive compensation on employee wages in different industries and find that the impacts are more severe in technology firms than in non-technology firms. Finally, we show that the executives with higher incentive compensation are more likely to suppress employee wages in financially safe firms. Our results suggest that while top management teams are compensated as a team on average, they are compensated as isolated individuals on other aspects. Furthermore, firm performance may not always improve in the long run by granting high incentive compensation to top executives.
\end{abstract}

Keywords: executive incentive compensation, pay-performance sensitivity, employee wages, agency conflicts

JEL codes: G30, J31, J33

\section{Introduction}

Agency conflicts between shareholders and managers with little or no ownership are inherent in modern corporations and can lead managers to divert the firm's resources for their own benefits (Jensen and Meckling, 1976). Equity-based compensation (EBC) is an important component in executive compensation package because it is efficient in aligning executives' interests with shareholders' interests (Jensen and Murphy, 1990; Murphy, 1999). Fama (1980) also argues that an efficient managerial labor market helps to enhance managers' performance because the managers' pay level is decided by their performance. Since Jensen and Murphy (1990) imply that executive incentives are weak by showing that CEO (chief executive officer) incentive compensation is low, the incentive compensation has more than doubled (Murph, 1999). As firms subsequently increase executive incentives, there are concerns about executives, who might utilize incentive compensation for their own interests at the expense of other stakeholders (Sappington \& Stiglitz, 2004).

Another stream in executive compensation study focuses on a perspective that top executives are compensated as a team or as individuals. Bushman, Dai, and Zhang (2016) examine pay-performance sensitivity (PPS) and its dispersion across top executives and find that firms consider top executives as a team and actively manage PPS dispersion for firm performance. $\mathrm{Li}$ (2018) also support the perspective that top management teams are compensated as teams. Other studies such as Pagano and Volpin (2005) and Bertrand and Mullainathan (2003) examine the relationship between employee wages and managerial powers.

While there are numerous papers on executive compensation, there are few papers examining the relationship between employee wages and executive compensation, especially the compensation of the top five executives. Graefe-Anderson et al. (2018) show that the CEO compensation policy has impacts on shareholders' wealth as well as on employee wages. Although Baum, Ford, and Zhao (2012) examine executive compensation by introducing a new pay-for-performance metric: the top five executives' share of core earnings, we adopt PPS to measure the equity-based compensation to the top five executives. Therefore, this study could provide insights on how top management teams are compensated. 
Using a sample from Execucomp database, Compustat, and CRSP during 1992-2017, we investigate the impacts of executive compensation on employee wages. In addition, we examine the relationship between employee wages and other factors such as firm size, leverage ratio, market-to-book ratio and physical capital intensity. We find that EBC to top five executives provided by PPS has significantly negative impacts on employee wages, which is consistent with the results by Graefe-Anderson et al. (2018). The two-stage regression analysis support that our results are robust over potential endogeneity. Running the Heckman two-step analysis, we show that the results persist with the small samples size in labor expenses. The finding that top five executives are compensated like CEOs on average can imply that executives are compensated as a team.

Further analysis shows that our results are opposite to findings by Graefe-Anderson et al. (2018). We find that EBC has negative impacts on employee wages in technology firms than on those in non-technology firms and that EBC has negative impacts more on those in financially safe firms than on those in financially distressed firms. The finding that top five executives are compensated unlike CEOs on different industries and business cycles can suggest that executives are compensation as individuals.

We contribute to the literature in three ways. First, we examine the relationship between executive EBC and employee wages. We show that executive $\mathrm{EBC}$ has negative impacts on employee wages. The firms' leverage has positive impacts on employee wages. In addition, the impacts from EBC to the top five executives are more severe in technology firms than in non-technology firms. Second, while top-five executives are compensated as a team in general, they appear to be compensated as individuals in different industries and business cycles. Third, our results suggest that the question on whether executives are compensated as a team or individuals might not be mutually exclusive.

The remainder of our paper is developed as follows. Section 2 reviews the relevant literature and hypotheses development. Section 3 describes our data and the models designed to test the hypotheses and robustness. Section 4 presents the empirical results and findings. Section 5 concludes the study.

\section{Literature Review and Hypotheses}

\subsection{Agency Conflicts and Executive Compensation}

The separation of ownership and management naturally brings attention to conflicts of interests. Jensen and Meckling (1976) argue that although managers are hired to maximize firm values, the conflict of interests between shareholders and managers leads managers to pursue their own benefits at the expense of shareholders' interest. Jensen (1986) shows that the agency conflict is more pronounced in firms with large free cash flows. Managers tend to increase firm size because increases in firm size are closely related to increases in their compensation (Murphy, 1985). Since these conflicts are unavoidable in modern corporations, shareholders design incentive compensation to align managers' interest with that of shareholders. After Jensen and Murphy (1990) find that CEO incentives are weak by showing that a typical CEO receives only $\$ 3.25$ for every $\$ 1,000$ increase in firm value, Kaplan (2012) finds that CEO compensation has increased significantly in the 1990s and then begun to decrease since then.

EBC is an important component in executive compensation packages because it is efficient in aligning executives' interests with shareholders' (Jensen and Murphy, 1990; Murphy, 1999). So EBC also has the effect of reducing agency conflicts. Jensen and Meckling (1976) argue that being granted more equity ownership, managers are more committed to increasing firm's value. Similarly, Fama (1980) also proposes that an efficient managerial labor market helps to enhance managers' performance because the managers' pay level is decided by their performance.

In the literature there are mixed reports on the relationship between the fraction of stocks granted to managers and the firm's market value. Morck et al. (1988) examine the relationship between the managers' stock fraction and Tobin's Q. They find that Tobin's Q increases when the fraction is between $0 \%$ and $5 \%$ and above $25 \%$, and then decreases when between 5\% and 25\%. Hermalin and Weisbach (1991) do the similar examination and obtain different findings. They consider the tenure of managers and find that the changing slope is positive when the fraction stays in the two intervals: $0 \%$ to $1 \%$ and $5 \%$ to $20 \%$, and then becomes negative when the fraction is between $1 \%$ and 5\% and larger than 20\%. On the other hand, Lorderer and Martin (1997) do not find the positive relationship between the firm performance and stock ownership granted to managers. They suggest that managers may waste corporate resources when they are granted large fraction of stocks.

In measuring EBC, Murphy (2012) suggests two quantities: pay-performance sensitivity (PPS) and pay-volatility sensitivity (PVS). Core and Guay (2002) define PPS as "Dollar change in the CEO's wealth associated with a 1\% change in the firm's stock price" and PVS as "Dollar change in the CEO's wealth associated with $1 \%$ change in the annualized standard deviation of stock returns". Following Core and Guay (2002), we measure PPS as the total dollar 
changes in the top five executives' wealth associated with a $1 \%$ change in the firm's stock price and PVS as the total dollar changes in the top five executives' wealth relative to a 0.01 change in the annualized standard deviation of stock returns.

\subsection{Studies on Employee Wages Relative to Executives}

Pagano and Volpin (2005) develop a theory on alliance between managers and workers and argue that when managers are allied with employees with significant voting rights, they are less affected by the discipline from the market for corporate control and tend to seek negative NPV (net present value) acquisitions for empire-building at the expense of shareholder value. Bertrand and Mullainathan (2003) examine the relationship between employee wages and managerial powers. They study plant-level data and show that when managers are protected from takeovers, white-collar employee wages increase.

Graefe-Anderson et al. (2018) examine the impacts of EBC to CEO on the employee wages with both incentive measures: PPS and PVS. They find evidence that as CEO incentive compensation provided by PPS increases, average employee wages declines. However, they do not find that PVS to CEO compensation affects employee wages. Furthermore, they show that employee wages are suppressed more in non-technology firms than in technology firms and more in financially distressed firms than in healthy firms, as CEO incentives rise.

\subsection{Compensation to Top Five Executives}

Baum, Ford and Zhao (2012) investigate the top five executives' share of core earnings to proxy for the executive compensation. By examining S\&P 500 companies from 1993 to 2007, they find that the top five executives' pay is related to firm performance and firm specific characteristics such as book-to-market ratio and equity risk. They also suggest that the increase in the total compensation is mainly driven by the increase in the restricted stocks and stock options. Edmans et al. (2018) model synergies in multi-agent optimal contracting and argue that top executives can be excluded from the team, depending on synergy impacts on other executives. That is, top executives can be compensated as isolated individuals. On the other hand, Bushman, Dai, and Zhang (2016) measure pay-performance sensitivity (PPS) and its deviation from optimal levels across top executives and show evidence that firms compensate top executives as a team and actively manage PPS dispersion toward optimal levels. Li (2018) supports the evidence that top management teams are compensated as teams.

We build on findings by Graefe-Anderson et al. (2018) to study the impacts of incentive compensation to top five executives on employee wages and to evaluate whether those executives are compensated as a team or as individuals. Hence, we establish our Hypothesis 1:

H1: Top five executives' compensation does suppress employee wages. That is, there is a negative relation between PPS of the top five executives and employee wages.

In the literature, capital structure is found to have significant influence on employee pay. High firm leverage leads to high probability to go bankrupt. To be compensated for the additional risk-taking from the higher bankruptcy possibility, employees may ask for higher wages. We also include leverage as one of the main control variables. Chemmanur et al. (2013) examine the relationship between firm leverage and average employee pay and find that the leverage has positive impacts on employee pay. Similarly, Graefe-Anderson et al. (2018) show evidence consistent with Chemmanur et al. (2013), using PPS as a main independent variable. We investigate whether this relationship still holds in the existent of EBC to the top five executives. Therefore, we have our Hypothesis 2:

H2: In the existent of EBC to the top five executives, firm leverage is positively related to average employee wages.

\subsection{EBC and Employee Wages Relative to Technology Firms}

Chemmanur et al. (2013) also study the impacts of leverage on CEO compensation and average employee wages both in technology and non-technology firms. They show that the leverage has greater impacts on both CEO pay and average employee wages in non-technology firms than in technology firms. Graefe-Anderson et al. (2018) also divide their data into the two groups and examine the impacts of CEO compensation on employee wages separately. They find evidence that CEOs suppress employee wages more in non-technology firms than in technology firms. Therefore, we establish our Hypothesis 3:

H3: There is difference in the influence of PPS to top five executives on average employee wages between technology and non-technology firms. 


\subsection{EBC and Employee Wages Relative to Business Cycle}

Business cycles lead to different financial states as well as different bankruptcy probabilities. That is, the bankruptcy probability is low when firms are in good states, while the probability is high when in bad states. Chemmanur et al. (2013) measure the bankruptcy probability using Z-score and divide the dataset into two subsets: financially safe firms and financially distressed firms. Their results show that the effect of firm leverage on average employee wages is significant in financially safe firms, while that is not significant in financially distressed firms.

In various financial states the impacts of EBC to executives on employee wages can be varied. Recently, Graefe-Anderson et al. (2018) examine the relationship between CEO EBC and employee wages during different business cycles. They adopt bankruptcy probability to measure the financial states and find evidence that the EBC has negative effects on employee wages for the firms in a bad state more than for firms in a good state. We expect that the impacts of EBC to top five executives on employee wages are varied for firms in different business cycles. Therefore, we establish Hypothesis 4:

\section{H4: EBC to the top five executives have different effects on employee wages in the different business cycles.}

\section{Data and Methodology}

\subsection{Data}

The compensation data for the top five executives are collected from Execucomp database during the period from January 1992 to December 2017. To calculate PPS and PVS, we obtain data on stock-related information from CRSP database. Since the data reporting format in Execucomp is changed since 2006, we follow the changes in calculating PPS and PVS. In addition, we use Black-Scholes-Merton model to calculate the option delta and vega. Delta is defined as the dollar change of executive EBC corresponding to a $1 \%$ change in stock price, while vega refers to the dollar change associated with a $1 \%$ change in the standard deviation of stock returns. We retrieve the monthly risk-free rates from historical data provided by the Federal Reserve website for "Treasury constant maturities". Consistent with the prior literature, we eliminate the finance and utility firms because those firms have different operating mechanisms and regulatory restrictions compared to the others.

We first calculate delta and vega of each executive for each company, and then sum up the delta and vega of the top five executives from each firm to be PPS and PVS, respectively. To maintain consistency among the variables in the regression model, we take the natural log of variables, including PPS and PVS. Deleting the missing values PPS, we have 219,378 executive-year observations and 35,512 firm-year observations during the sample period. There are 301 unique firms that have non-missing data for our dependent and independent variables. We obtain data on firm characteristics from COMPUSTAT. We calculate average employee wage as "Staff expense" (XLR) divided by "Number of employees" (EMP), which are available from COMPUSTAT database. Among the 2,810 unique firms, we have only 309 unique firms that report their employee wages. Since only $11 \%$ of the firms report their "Staff expenses" data, there are concerns on sample-selection bias. We conduct the Heckman two-step test to address the potential bias concern.

We also include important control variables such as firm size, leverage ratio, average sales per employee, market-to-book ratio (MTB), physical capital intensity (PCI), and quit rates. We estimate the firm size with market capitalization, which is computed as the number of common shares outstanding multiplied by current market prices. Based on the method used by Leary and Roberts (2010), we measure leverage as market leverage ratios, which are computed as the total debt (DLTT+DLC) divided by the sum of the total debt and market value of equity (CSHO*PRCC_F). The variable, average sales per employee, is calculated as the sales divided by the number of employees (SALE/EMP). The market-to-book ratio is defined as the market value of assets to the book value of assets (Coles et al., 2006). We use physical capital intensity to reflect the growth opportunities of the firm. Following Chemmanur et al. (2013), we compute physical capital intensity as the gross property, plant and equipment scaled by total assets (PPEGT/AT). We collect quit rates from the database of Job Openings and Labor Turnover Survey (JOLTS) provided by the U.S. Bureau of Labor Statistics. To capture the industry effects in our regression models, we categorize firms into different industries by the Standard Industrial Classification (SIC) codes and construct industry dummies.

Table 1 reports the summary statistics of the key variables used in the regression analysis. We present the statistics of PPS and PVS for both CEO and the top five executives. The dependent variable, average employee wage, has a mean of $\$ 56,339$, a median of $\$ 51,571$ and a standard deviation of $\$ 38,630$. PPS of CEO has a mean of $\$ 701,436$ and a median of $\$ 205,986$. Graefe-Anderson et al. (2018) examine PPS of CEO from 1992 to 2014 and find that PPS has a mean of $\$ 879,276$ and a median of $\$ 205,999$. The different results between their study and ours might reflect the 
different sample periods and the decline of CEO compensation over time. Meanwhile, PPS of the top five executives has a mean of $\$ 1,134,104$ and a median of $\$ 472,720$. The mean value indicates that the equity-based compensation of the top executives changes by $\$ 1,134,104$ corresponding to per $1 \%$ change in the firm's stock price. PVS of the top five executives has a mean of $\$ 213,004$, which means that the equity-based compensation of the top five executives changes by $\$ 213,004$ when there is a $1 \%$ change in the annualized standard deviation of stock returns.

Table 1. Descriptive statistics of key variables

\begin{tabular}{ccrrrrrrr}
\hline Variable & $\mathrm{N}$ & \multicolumn{1}{c}{ Mean } & \multicolumn{1}{c}{ Std. Dev. } & \multicolumn{1}{c}{ Min } & \multicolumn{1}{c}{ Q1 } & Median & \multicolumn{1}{c}{ Q3 } & \multicolumn{1}{c}{ Max } \\
\hline Wage & 2,860 & $56,338.86$ & $38,629.96$ & $7,161.73$ & $31,166.35$ & $51,571.04$ & $71,950.20$ & $213,024.11$ \\
PPS(CEO) & 2,860 & $701,435.5$ & $2,069,810.1$ & 0.00 & $86,603.53$ & $205,985.8$ & $572,313.62$ & $38,418,652.5$ \\
PPS & 2,860 & $1,134,103$. & $1,847,618.9$ & $8,560.51$ & $187,686.3$ & $472,720.0$ & $1,229,150.3$ & $11,727,599.6$ \\
PVS(CEO) & 2,860 & $94,018.15$ & $226,946.49$ & 0.00 & 10.14 & $12,773.67$ & $89,318.36$ & $3,213,652.08$ \\
PVS & 2,860 & $213,004.2$ & $394,823.99$ & 0.00 & 71.61 & $52,486.02$ & $237,988.17$ & $2,303,322.33$ \\
Size & 2,860 & 21.47 & 1.64 & 17.58 & 20.35 & 21.35 & 22.65 & 25.30 \\
Leverage & 2,860 & 0.25 & 0.22 & 0.00 & 0.08 & 0.19 & 0.35 & 0.92 \\
Avgsale & 2,860 & $239,532.1$ & $247,657.54$ & $23,533.2$ & $93,300.94$ & $170,443.7$ & $287,547.15$ & $1,477,569.62$ \\
MTB & 2,860 & 3.31 & 3.88 & 0.00 & 1.49 & 2.33 & 3.74 & 29.65 \\
PCI & 2,860 & 0.77 & 0.42 & 0.05 & 0.41 & 0.78 & 1.08 & 1.84 \\
\hline
\end{tabular}

Wage is the average employee wages in the firm. PPS(CEO) and PVS(CEO) are PPS and PVS for CEO, respectively. PPS and PVS are the total PPS and PVS of the top five executives, respectively. Size represents the firm size; Leverage is the firm market leverage ratio; Avgsale is the average sales per employee; MTB is market-to-book ratio; PCI is the physical capital intensity; The sample period is 1992 - 2017. The units of the data on Wage, PPS, PVS and Avgsale are one dollar.

Table 2 presents the sample correlations of key variables. We observe that almost all of the correlations are significant at the $1 \%$ level, which suggests that the change in one variable is significantly related to the change in another variable. Moreover, "Wage" and "Average sales" have a strong relationship with a coefficient of 0.726 . The absolute value of coefficients of the correlations of "PVS" and "Size", "Size" and "Avgsale" are between 0.3 and 0.5, which implies that the variables have a moderate degree of correlations. The absolute value of coefficients of the correlations of the other two variables are below 0.29 , which indicates a weak relationship between the two.

Table 2. Correlations of key variables

\begin{tabular}{cllllllll}
\hline & Wage & PPS & PVS & Size & Leverage & Avgsale & MTB & PCI \\
\hline Wage & $\mathbf{1}$ & & & & & & & \\
PPS & $\mathbf{0 . 0 4 0}$ & $\mathbf{1}$ & & & & & & \\
PVS & $\mathbf{- 0 . 0 9 6}$ & $\mathbf{0 . 4 1 3}$ & $\mathbf{1}$ & & & & & \\
Size & $\mathbf{0 . 2 2 1}$ & $\mathbf{0 . 5 7 0}$ & $\mathbf{0 . 3 0 8}$ & $\mathbf{1}$ & & & & \\
Leverage & $\mathbf{0 . 1 2 8}$ & $\mathbf{- 0 . 2 8 5}$ & $\mathbf{- 0 . 1 3 9}$ & $\mathbf{- 0 . 1 7 1}$ & $\mathbf{1}$ & & & \\
Avgsale & $\mathbf{0 . 7 2 6}$ & $\mathbf{0 . 0 7 8}$ & $\mathbf{- 0 . 0 4 9}$ & $\mathbf{0 . 3 1 2}$ & $\mathbf{0 . 0 7 5}$ & $\mathbf{1}$ & & \\
MTB & $\mathbf{- 0 . 0 5 1}$ & $\mathbf{0 . 2 1 7}$ & $\mathbf{0 . 0 9 9}$ & $\mathbf{0 . 3 0 6}$ & $\mathbf{- 0 . 2 4 4}$ & -0.014 & $\mathbf{1}$ & \\
PCI & $\mathbf{- 0 . 2 1 2}$ & $\mathbf{- 0 . 0 6 0}$ & 0.025 & -0.027 & $\mathbf{0 . 1 1 2}$ & $\mathbf{- 0 . 1 2 9}$ & $\mathbf{- 0 . 0 5 0}$ & $\mathbf{1}$ \\
\hline
\end{tabular}

This table shows Pearson correlations between the key variables. Wage is the natural log of average employee wages; PPS is the natural log of the total PPS of the top five executives; PVS is the natural log of the total PPS of the top five executives of the firm; Size is the firm size; Leverage is the firm market leverage ratio; Average sales is the natural $\log$ of the average sales per employee; MTB is market-to-book ratio of the firm; PCI is the physical capital intensity of the firm; The sample contains 35,512 firm-year observations during 1992 - 2017; Boldface indicates significance at $1 \%$ level 


\subsection{Equity-Based Compensation to Executives}

Core and Guay (2002) calculate the option values based on the Black-Scholes (1973) model for European call options, which is modified by Merton (1973) to add dividends as below.

$$
\text { option value }=S e^{(-d T)} N(Z)-X e^{(-r T)} N(Z-\sigma \sqrt{T})
$$

where $Z=\ln \left(\frac{S}{X}\right)+T\left(r-d+\frac{\sigma^{2}}{2}\right) / \sigma \sqrt{T}, N$ is a cumulative probability function for normal distribution, $\mathrm{S}$ is a price of the underlying stock, $X$ is an exercise price of the option, $\sigma$ is volatility of stock returns over the life of the option, $r$ is a risk-free interest rate, $T$ is time to maturity of the option in years, $d$ is an expected dividend yield over the life of the option.

Following Core and Guay (2002), we calculate delta and vega for each executive per year. We add up the delta of both exercisable and unexercisable options and the delta of shareholdings, and sum the vega of both exercisable and unexercisable options. We add up all deltas and vegas of the top five executives in each firm to obtain the total PPS and total PVS for each firm-year. Hence, we estimate PPS as the following:

$$
\begin{aligned}
& {\left[\frac{\partial(\text { option value })}{\partial(\text { stock volatility })}+\# \text { shr.own }\right] \times\left(\frac{\text { stock price }}{100}\right)} \\
& =\left[e^{(-d T)} N(Z) \times \# \text { options }+\# \text { shr.own }\right] \times\left(\frac{\text { stock price }}{100}\right),
\end{aligned}
$$

and PVS as:

$$
\frac{\partial(\text { option value })}{\partial(\text { stock volatility })} \times 0.01=e^{-d T} N^{\prime}(Z) \times S \sqrt{T} \times 0.01 \times \# \text { options }
$$

where $\mathrm{N}$ is a normal distribution function.

\subsection{Employee Wages, Capital Structure and Pay-Performance Sensitivity}

To test, Hypothesis 1 and Hypothesis 2, we run an OLS model with year and industry dummy variables.

$$
\begin{aligned}
\text { wage }_{i, t}= & \alpha_{0}+\alpha_{1} \mathrm{PPS}_{i, t}+\alpha_{2} \mathrm{pvs}_{i, t}+\alpha_{3} \text { size }_{i, t}+\alpha_{4} \mathrm{Lev}_{i, t}+\alpha_{5} \text { avgsale }_{i, t} \\
& +\alpha_{6} \mathrm{MTB}_{i, t}+\alpha_{7} \mathrm{PCI}_{i, t}+\alpha_{8} \text { quits }_{i, t}+\text { year }_{t}+\text { ind }_{i, t}+\varepsilon_{i, t}
\end{aligned}
$$

where wage $\mathrm{i}_{\mathrm{i}, \mathrm{t}}$ is calculated as the natural $\log$ of the average employee wage of firm $i$ in the year $t$; PPS $_{\mathrm{i}, t}$ is the natural $\log$ of the total PPS to the top five executives. PVS $\mathrm{i}_{\mathrm{i}, \mathrm{t}}$ is the natural $\log$ of the total PVS to the top five executives. We add "quits" for quits rate, which is the percentage of an industry's entire employment that quit their job by choice, as a proxy for labor specialization: high quits rates are related to lower labor specialization. Chemmanur et al (2013) show that employee wages are negatively related to the quits rate. We include a year dummy variable and an industry dummy variable. For Hypothesis 2 we expect the coefficient of Leverage $\alpha_{4}$ to be positive. Since avgsale $e_{i, t}$ is used to gauge the productivity of employees, we expect $\alpha_{5}$ to be positive. As Berk et al. (2010) find evidence that more capital-intensive firms tend to pay employees higher wages, we expect $\alpha_{7}$ to be positive.

\subsection{Heckman Two-Step Analysis}

Since many firms do not report labor expenses, there could be a potential sample selection bias (Chemmanur et al., 2013). More specifically, if firms with high EBC to executives and high employee wages choose not to report labor expenses, our regression results will be biased and spurious. To overcome this concern, we conduct Heckman (1979) two-step analysis, which proposes the two-step model to solve for the ordinary specification bias that arises from a missing data problem.

In the first step, our dependent variable, Pro $_{i, t}$, is one if the firm reports the data of labor expenses and zero otherwise. We run the Probit model to examine whether the data on employee pay is missing. We also include a dummy 
variable for firm's exchange listings to reflect the different reporting behaviors by firms in a specific exchange. The first step model is:

$$
\begin{aligned}
\operatorname{Pro}_{i, t}= & \alpha_{1} \mathrm{PPS}_{i, t}+\alpha_{2} \text { size }_{i, t}+\alpha_{3} \mathrm{Lev}_{i, t}+\alpha_{4} \text { avgsale }_{i, t}+\alpha_{5} \mathrm{MTB}_{i, t} \\
& +\alpha_{6} \mathrm{PCI}_{i, t}+\text { year }_{t}+\text { ind }_{i, t}+\operatorname{exchg}_{i, t}+\varepsilon_{i, t}
\end{aligned}
$$

In the second step, we select only the firms of which the data on employee wage is non-missing and run the OLS regression model to test the impacts of PPS on employee wages as below:

$$
\begin{aligned}
\text { wage }_{i, t}= & \beta_{0}+\beta_{1} \mathrm{PPS}_{i, t}+\beta_{2} \text { size }_{i, t}+\beta_{3} \mathrm{Lev}_{i, t}+\beta_{4} \text { avgsale }_{i, t}+\beta_{5} \mathrm{MTB}_{i, t} \\
& +\beta_{6} \mathrm{PCI}_{i, t}+\beta_{7} \mathrm{Imr}_{i, t}+\text { year }_{t}+\text { ind }_{i, t}+\varepsilon_{i, t},
\end{aligned}
$$

where $\operatorname{Imr}_{\mathrm{i}, \mathrm{t}}$ is the inverse Mill's ratio, which is generated in the first step. Heckman (1979) and Tobin (1958) propose that the inverse Mill's ratio can make the parameters derived from the regression model unbiased.

\subsection{Employee Wages in Technology Firms Versus Non-technology Firms}

In testing Hypothesis 3, we study the impacts of PPS on employee wages in different industries. Using SIC code, we divide our data into two groups: technology firms and non-technology firms. (Note 1) Then we run the regression for the technology and the non-technology firms separately.

$$
\begin{aligned}
\text { wage }_{i, t}= & \gamma_{0}+\gamma_{1} \mathrm{PPS}_{i, t}+\gamma_{2} \text { size }_{i, t}+\gamma_{3} \mathrm{Lev}_{i, t}+\gamma_{4} \text { avgsale }_{i, t} \\
& +\gamma_{5} \mathrm{MTB}_{i, t}+\gamma_{6} \mathrm{PCI}_{i, t}+\text { year }_{t}+\text { ind }_{i, t}+\varepsilon_{i, t} .
\end{aligned}
$$

To examine whether the coefficients of PPS are statistically different between technology and non-technology firms, we conduct a Wald test.

\subsection{Employee Wages During Different Business Cycles}

For Hypothesis 4, we divide the sample into two different business cycles by bankruptcy probabilities. To measure the bankruptcy probability, we follow the method of Cole, Daniel and Naveen (2006) and Chemmanur et al. (2013) based on the method by Altman (1968). They calculate Z-score as:

$$
\text { Z-score }=1.2 T_{1}+1.4 T_{2}+3.3 T_{3}+0.6 T_{4}+T_{5},
$$

where $T_{1}$ is working capital/total assets, $T_{2}$ is retained earnings/total assets, $T_{3}$ is earnings before interest and taxes/total assets, $T_{4}$ is market value of equity/book value of total liabilities, and $T_{5}$ is sales/total assets.

Based on Z-score, we divide the sample into financially safe firms and distressed firms. Chemmanur et al. (2013) define the firms with Z-score above or equal to 2.99 to be financially safe firms, and those with Z-score below or equal to 1.8 to be financially distressed firms. We run the regression of model Eq.(7) for the financially safe and distressed firms separately. We conduct a Wald test to examine whether the coefficients of PPS in a group are significantly different from those in the other group.

\subsection{Robustness Tests}

To address concerns on endogeneity and alternative variable measures, we conduct robustness tests. Recall that leverage ratios reflect the investment opportunities of the firm. That is, the firm's leverage ratio will increase with investment. Harris and Raviv (1991) and Parsons and Titman (2009) suggest that if a firm has high leverage, it implies that the firm has a large amount of investment or tangible assets to manage. To ensure investments or assets to be well operated, firms need to pay employees high wages. Therefore, the positive relationship between employee wages and leverage creates the potential endogeneity concern. To address the concern, we conduct the two-stage least square (2SLS) regression following Wooldridge (2002).

In the first stage, we introduce an instrumental variable, which is related to leverage but not related to the employee wages. Since the tax benefit of debt is positively related to a firm's marginal tax rate, there is also a positive relation between the marginal tax rate and the firm's leverage ratio (Leary and Roberts, 2010). We could not find the literature suggesting that there is a direct relation between marginal tax rate and average employee wages. Following Givoly et al. (1992) and Chemmanur et al. (2013), we use marginal tax rates based on income before interest expenses as the instrument variable because it meets the requirements above. In the spirit of Chemmanur et al. 
(2013), we add the variable $(E B I T / A T)_{i, t}$ as a proxy for the efficiency of a firm in generating profits from its assets. We also include $S T D(E B I T / A T)_{i, t}$ to measure the volatility of firm's efficiency in generating returns from assets. The model in the first step is shown below:

$$
\begin{aligned}
\mathrm{Lev}_{i, t}=\theta_{0} & +\mathrm{PPS}_{i, t}+\theta_{2} \text { size }_{i, t}+\theta_{3} \text { avgsale }_{i, t}+\theta_{4} \mathrm{MTB}_{i, t}+\theta_{5} \mathrm{PCI}_{i, t} \\
& +\theta_{6} \mathrm{MTR}_{i, t}+\theta_{7}(\mathrm{EBIT} / \mathrm{AT})_{i, t}+\theta_{8} \mathrm{STD}(\mathrm{EBIT} / \mathrm{AT})_{i, t}+\text { year }_{t}+\varepsilon_{i, t},
\end{aligned}
$$

From the first step, we obtain the fitted value of leverage ratio and use it as an independent variable in the second step. The model for the second step is shown as

$$
\begin{aligned}
\text { wage }_{i, t}= & \alpha_{0}+\alpha_{1} \mathrm{PPS}_{i, t}+\alpha_{2} \text { size }_{i, t}+\alpha_{3} \mathrm{Lev}_{i, t}+\alpha_{4} \text { avgsale }_{i, t}+\alpha_{5} \mathrm{MTB}_{i, t} \\
& +\alpha_{6} \mathrm{PCI}_{i, t}+\alpha_{7}(\mathrm{EBIT} / \mathrm{AT})_{i, t}+\alpha_{8} \mathrm{STD}(\mathrm{EBIT} / \mathrm{AT})_{i, t}+\text { year }_{t}+\varepsilon_{i, t}
\end{aligned}
$$

In addition, we introduce another measure for the executives' performance to further test the robustness. Consistent with Graefe-Anderson et al. (2018), we adopt the excess return (Exret $\left.{ }_{i, t}\right)$ and add a cross product term of PPS and excess returns. The model is shown as:

$$
\begin{aligned}
\text { wage }_{i, t}= & \theta_{0}+\theta_{1} \mathrm{PPS}_{i, t}+\theta_{2} \text { size }_{i, t}+\theta_{3} \mathrm{Lev}_{i, t}+\theta_{4} \text { avgsale }_{i, t}+\theta_{5} \mathrm{MTB}_{i, t} \\
& +\theta_{6} \mathrm{PCI}_{i, t}+\theta_{7} \text { exret }_{i, t}+\theta_{8}(\text { exret } \times \mathrm{PPS})_{i, t}+\text { year }_{t}+\text { ind }_{i, t}+\varepsilon_{i, t}
\end{aligned}
$$

\section{Results}

\subsection{Summary of Compensation to Executives and Employees}

We examine the income disparity during the following three sub-periods: 1992-2000, 2001-2007 and 2008-2017. Table 3 reports average employee wages, total operating expenses and the ratio of average employee wages to the annual operating expense. We observe that the employee wages increase from period 1 to period 2 and then go down from period 2 to period 3. The ratio of employee wages to operating expenses declines over the three periods. We note that employee wages occupy a very high portion of the operating expenses.

Table 3. Executive compensation and employee wages

\begin{tabular}{crrr}
\hline Compensation & $\begin{array}{r}\text { Period 1 } \\
(1992-2000)\end{array}$ & $\begin{array}{r}\text { Period 2 } \\
(2001-2007)\end{array}$ & $\begin{array}{r}\text { Period 3 } \\
(2008-2017)\end{array}$ \\
\hline Staff Expenses & $1,925,181,351$ & $2,208,144,646$ & $2,029,027,891$ \\
Operating Expenses & $3,313,323,933$ & $4,583,042,627$ & $6,066,920,769$ \\
Ratio of Staff Expenses to Operating Expenses & 0.58 & 0.48 & 0.33 \\
TDC1--CEO & $3,968,010$ & $5,244,069$ & $5,943,852$ \\
TDC2--CEO & $3,576,109$ & $5,501,672$ & $7,468,717$ \\
PPS--CEO & $1,408,134$ & $1,271,301$ & 759,834 \\
TDC1--Top 5 Executives & $1,856,860$ & $2,410,678$ & $3,754,691$ \\
TDC2--Top 5 Executives & $1,511,852$ & $2,424,094$ & $4,311,489$ \\
PPS--Top 5 Executives & $2,262,338$ & $2,220,253$ & $1,281,237$ \\
Average Employee Wage & 58,347 & 54,731 & 71,161 \\
\hline
\end{tabular}

This table shows the average annual compensation to CEO, top five executives and employees as well as the average annual staff expenses and operating expenses during the three time periods: from 1992 to 2000; from 2001 to 2007; from 2008 to 2017. TDC1 is the total compensation which is comprised of: salary, bonus, other annual, total value of restricted stock granted, total value of stock options granted (using Black-Scholes), long-term incentive payouts, and all other total. TDC2 is also the total compensation which is measured in another way. TDC2 is composed of the following: salary, bonus, other annual, total value of restricted stock granted, net value of stock options exercised, long-term incentive payouts, and all other total. PPS is the Pay Performance Sensitivity. All the data items are collected individually. The units of the data on Staff Expenses, Operating Expenses, TDC1, TDC2, PPS and Average Employee Wage are one dollar. 
In executive compensation, we find that the average annual compensation to the top five executives is about 26-60 times to that of average employee wages. The situation is even worse to CEO, which is 61-100 times to that of average employee wages. This huge income disparity between employees and executives might discourage employees and have negative impacts on firm performance. Kong (2017) suggests that high CEO Pay Slice (CPS) could have a negative impact on firm performance by demotivating employees and destroying team cooperation.

\subsection{Employee Wages Analysis}

Table 4 exhibits the relation between employee wages and CEO compensation as in Graefe-Anderson et al. (2018). The first five columns show the relation between employee wages and PPS of CEO along with the control variables. The last column shows the relation of employee wages and PVS of CEO. The significantly negative coefficients of PPS indicate the negative impacts of CEO PPS on employee wages, consistent with Graefe-Anderson et al. (2018). Positive coefficients in leverage ratios show that higher leverage ratios lead to higher employee wages as in Chemmanur et al. (2013) and Graefe-Anderson et al. (2018).

Table 4. Regressions on employee with CEO

\begin{tabular}{|c|c|c|c|c|c|c|}
\hline Wage & (1) & (2) & (3) & (4) & (5) & (6) \\
\hline \multirow[t]{2}{*}{ PPS } & $-0.0170^{*}$ & $-0.0174 * * *$ & $-0.0171 * * *$ & $-0.0175 * * *$ & $-0.0137^{*}$ & \\
\hline & $(0.0057)$ & $(0.0057)$ & $(0.0057)$ & $(0.0057)$ & $(0.0072)$ & \\
\hline \multirow[t]{2}{*}{ PVS } & & & & & & 0.0002 \\
\hline & & & & & & $(0.0023)$ \\
\hline \multirow[t]{2}{*}{ Firm size } & $0.0240 * *$ & $0.0281 * * *$ & $0.0232 * * *$ & $0.0271 * * *$ & $0.0198 * * *$ & $0.0197 * * *$ \\
\hline & $(0.0053)$ & $(0.0057)$ & $(0.0055)$ & $(0.0057)$ & $(0.0074)$ & $(0.0058)$ \\
\hline \multirow[t]{2}{*}{ Leverage } & $0.2860 * *$ & $0.2695 * * *$ & $0.2653 * * *$ & $0.2497 * * *$ & $0.2817 * * *$ & $0.2696 * * *$ \\
\hline & $(0.0365)$ & $(0.0369)$ & $(0.0364)$ & $(0.0368)$ & $(0.0452)$ & $(0.0382)$ \\
\hline \multirow[t]{2}{*}{ Average sales } & $0.4462 * *$ & $0.4451 * * *$ & $0.4572 * * *$ & $0.4561 * * *$ & $0.4854 * * *$ & $0.4773 * * *$ \\
\hline & $(0.0129)$ & $(0.0129)$ & $(0.0129)$ & $(0.0129)$ & $(0.0162)$ & $(0.0139)$ \\
\hline \multirow[t]{2}{*}{ MTB } & & $-0.0058 * * *$ & & $-0.0055 * * *$ & $-0.0054 * *$ & $-0.0059 * * *$ \\
\hline & & $(0.0020)$ & & $(0.0020)$ & $(0.0026)$ & $(0.0021)$ \\
\hline \multirow[t]{2}{*}{ PCI } & & & $0.1527 * * *$ & $0.1513 * * *$ & $0.1757 * * *$ & $0.1579 * * *$ \\
\hline & & & $(0.0240)$ & $(0.0240)$ & $(0.0314)$ & $(0.0253)$ \\
\hline \multirow[t]{2}{*}{ Quits } & & & & & $-0.2362 * * *$ & \\
\hline & & & & & $(0.0313)$ & \\
\hline \multirow[t]{2}{*}{ Intercept } & $4.4343 * *$ & $4.3932 * * *$ & $4.1625 * * *$ & $4.1257 * * *$ & $3.1701 * * *$ & $3.7655 * * *$ \\
\hline & $(0.1664)$ & $(0.1668)$ & $(0.1705)$ & $(0.1709)$ & $(0.2631)$ & $(0.1848)$ \\
\hline Year Dummy & Yes & Yes & Yes & Yes & Yes & Yes \\
\hline Industry Dummy Dummy Dummy dummy & Yes & Yes & Yes & Yes & Yes & Yes \\
\hline Obs. & 2,860 & 2,860 & 2,860 & 2,860 & 1,724 & 2,392 \\
\hline Adj. $\mathrm{R}^{2}$ & 0.7743 & 0.7749 & 0.7777 & 0.7782 & 0.7835 & 0.7771 \\
\hline
\end{tabular}

This table reports the coefficients and standard errors of the regressions in the OLS regression model of employee wage and CEO PPS. The dependent variable is the average employee wages. We take the natural log of the wages and label them as "Wage" in the table. PPS is the natural log of the total Pay Performance Sensitivity of CEO; PVS is the natural log of the total Pay Volatility Sensitivity of CEO of the firm. Quits rate is collected from 2001 to 2017. The other variables in the data sample range from fiscal year 1992 to 2017. Numbers in the parentheses are the standard errors. $*, * *$ and $* * *$ indicate statistical significance at $10 \%, 5 \%$ and $1 \%$ level, respectively.

Table 5 reports the relation between employee wages and total PPS to the top five executives (referred to PPS from now on) along with control variables. The first four columns show that all coefficients of PPS are significantly negative at the $1 \%$ level. Using the coefficient at -0.0184 to PPS in Column 1 , we compute the incremental wage 
changes relative to the changes in PPS. With a median PPS at $\$ 472,720$ in Table 1 , we find that the level of the natural $\log$ of PPS increases by 1.5910 when a firm increases PPS by one standard deviation $(\$ 1,847,619)$. As a result, the natural log of average employee wages decreases by $0.0293(=0.0184 \times 1.5910)$. Applying to the median value of employee wage in Table 1, we find that the natural log of employee wage declines from 10.8507 to 10.8214 $(=10.8507-0.0293)$, which are translated from $\$ 51,571$ to $\$ 50,081$. Hence, the average employee wage decreases by $\$ 1,490$ when the incentive compensation to top five executives increases by one standard deviation. While the decreased amount might appear to be economically insignificant, it is indeed economically significant because average employee wages drop when compensation to top five executives increases $\$ 1.8$ million.

Table 5. Regressions on employee and top five executives

\begin{tabular}{|c|c|c|c|c|c|c|}
\hline Wage & (1) & (2) & (3) & (4) & (5) & (6) \\
\hline \multirow[t]{2}{*}{ PPS } & $-0.0184 * * *$ & $-0.0183 * * *$ & $-0.0185^{* * *}$ & $-0.0184 * * *$ & $-0.0192 *$ & \\
\hline & $(0.0066)$ & $(0.0066)$ & $(0.0066)$ & $(0.0066)$ & $(0.0113)$ & \\
\hline \multirow[t]{2}{*}{ PVS } & & & & & & -0.0029 \\
\hline & & & & & & $(0.0020)$ \\
\hline \multirow[t]{2}{*}{ Firm size } & $0.0261 * * *$ & $0.0293 * * *$ & $0.0253 * * *$ & $0.0283^{* * *}$ & $0.0127^{*}$ & $0.0269 * * *$ \\
\hline & $(0.0058)$ & $(0.0059)$ & $(0.0058)$ & $(0.0059)$ & $(0.0104)$ & $(0.0054)$ \\
\hline \multirow[t]{2}{*}{ Leverage } & $0.2982 * * *$ & $0.2852 * * *$ & $0.2755^{* * *}$ & $0.2634 * * *$ & $0.1572 * * *$ & $0.2891 * * *$ \\
\hline & $(0.0348)$ & $(0.0352)$ & $(0.0347)$ & $(0.0351)$ & $(0.0586)$ & $(0.0357)$ \\
\hline \multirow[t]{2}{*}{ Average sales } & $0.4491 * * *$ & $0.4484 * * *$ & $0.4597 * * *$ & $0.4590 * * *$ & $0.4230 * * *$ & $0.4736 * * *$ \\
\hline & $(0.0125)$ & $(0.0125)$ & $(0.0125)$ & $(0.0125)$ & $(0.0177)$ & $(0.0131)$ \\
\hline \multirow[t]{2}{*}{ MTB } & & $-0.0049 * * *$ & & $-0.0046^{* *}$ & $-0.0067^{*}$ & $-0.0058 * * *$ \\
\hline & & $(0.0020)$ & & $(0.0020)$ & $(0.0035)$ & $(0.0020)$ \\
\hline \multirow[t]{2}{*}{ PCI } & & & $0.1551 * * *$ & $0.1540 * * *$ & $-0.1815 * * *$ & $0.1606 * * *$ \\
\hline & & & $(0.0230)$ & $(0.0230)$ & $(0.0317)$ & $(0.0239)$ \\
\hline \multirow[t]{2}{*}{ Quits } & & & & & $-0.2345 * * *$ & \\
\hline & & & & & $(0.0164)$ & \\
\hline \multirow[t]{2}{*}{ Intercept } & $4.3604 * * *$ & $4.3211 * * *$ & $4.0913 * * *$ & $4.0564 * * *$ & $6.3987 * * *$ & $3.6484 * * *$ \\
\hline & $(0.1596)$ & $(0.1603)$ & $(0.1633)$ & $(0.1638)$ & $(0.2893)$ & $(0.1746)$ \\
\hline Year Dummy & Yes & Yes & Yes & Yes & Yes & Yes \\
\hline Industry Dummy ddddDdummy & Yes & Yes & Yes & Yes & Yes & Yes \\
\hline Obs. & 2,860 & 2,860 & 2,860 & 2,860 & 1,818 & 2,640 \\
\hline Adj. $\mathrm{R}^{2}$ & 0.7769 & 0.7774 & 0.7804 & 0.7808 & 0.5676 & 0.7780 \\
\hline
\end{tabular}

This table reports the coefficients and standard errors of the regressions in the OLS regression model of Employee Wage. The dependent variable is the average employee wages. We take the natural log of the wages and label them as "Wage" in the table. PPS is the natural log of the total Pay Performance Sensitivity of the top five executives; PVS is the natural $\log$ of the total Pay Volatility Sensitivity of the top five executives of the firm. Quits rate is collected from 2001 to 2017. The other variables in the data sample range from fiscal year 1992 to 2017. Numbers in the parentheses are the standard errors. $* * *$ and $* * *$ indicate statistical significance at $10 \%, 5 \%$ and $1 \%$ level, respectively.

Regarding other control variables in Table 5, firm size, leverage, average sales per employee and physical capital intensity have significantly positive coefficients. The results indicate that firms with larger size pay more to employees, which is consistent with Brown and Medoff (1989). Employees are paid higher if firms make higher sales because average sales per employee measure the employee productivity. Firms also pay their employees more if they increase leverage ratios to compensate additional risk-taking. These findings are consistent with Chemmanur et al. (2013). 
Furthermore, in Column 2 and Column 4-6, we find that the market-to-book ratio has significantly negative coefficients, which implies that growth firms pay to their employees less than do value firms. In addition, Column 3, Column 4, and Column 6 show that physical capital intensity has significantly positive coefficients as in Graefe-Anderson et al. (2018). It suggests that employees are paid more when firms have more growth opportunities. In Column 5, we add quits rate as a control variable and observe significantly negative coefficients, suggesting that employees get paid more if firms are more specialized as in Chemmanur et al. (2013). As Graefe-Anderson et al. (2018) find that the quits rate is not significant with PPS of CEO as a main variable, we conjecture that the difference might reflect that some executives are compensated as isolated individuals rather than as a team.

In Column 6 of Table 5, we use PVS as the proxy for EBC to executives instead of PPS. We note that PVS has a coefficient of -0.0029 , which is not significant. Since there is no significant relation between PVS and employee wages, we use PPS as a proxy for incentive compensation from now on.

\subsection{Heckman Two-Step Analysis}

Since many firms do not report staff expenses and the data on average employee wages of those firms are missing, we conduct the Heckman two-step analysis to address the concern on the potential sample selection bias. In Panel A of Table 6 for the first step, we find that coefficients of PPS in all the columns are significantly negative at the $1 \%$ level. Firm size and leverage have significantly positive coefficients as well. Average sales per employee have negative coefficients. In Column 2 and Column 4, market-to-book ratio has significantly negative coefficients. In Column 3 and Column 4, physical capital intensity has positive coefficients which are significant at the $1 \%$ level. The results suggest that larger firms with higher leverage, lower average sales per employee, lower market-to-book ratio, and higher physical capital intensity have higher probability of reporting staff expenses. These results are consistent with Graefe-Anderson et al. (2018).

Table 6. Heckman two step analysis

\begin{tabular}{|c|c|c|c|c|}
\hline Pro & (1) & (2) & (3) & (4) \\
\hline PPS & $-0.0423 * * *(0.0097)$ & $-0.0416 * * *(0.0097)$ & $-0.0284 * * *(0.0099)$ & $-0.0272 * * *(0.0101)$ \\
\hline Firm size & $0.1496 * * *(0.0094)$ & $0.1549 * * *(0.0095)$ & $0.1455 * * *(0.0095)$ & $0.1361 * * *(0.0101)$ \\
\hline Leverage & $0.3048 * * *(0.0634)$ & $0.2791 * * *(0.0644)$ & $0.2456 * * *(0.0642)$ & $0.1942 * * *(0.0669)$ \\
\hline Average sales & $-0.2354 * * *(0.0174)$ & $-0.2354 * * *(0.0175)$ & $-0.2199 * * *(0.0178)$ & $-0.2210 * * *(0.0180)$ \\
\hline MTB & & $-0.0104 * * *(0.0036)$ & & $-0.0092 * *(0.0036)$ \\
\hline PCI & & & $0.5743 * * *(0.0380)$ & $0.5619 * * *(0.0384)$ \\
\hline Exchange Dummy & Yes & Yes & Yes & Yes \\
\hline Year Dummy & Yes & Yes & Yes & Yes \\
\hline Industry Dummy & Yes & Yes & Yes & Yes \\
\hline Obs. & 30,856 & 30,856 & 30,856 & 30,856 \\
\hline
\end{tabular}

Panel B: Second step--Regression of employee wages in firms with data on employee wages

\begin{tabular}{cllll}
\hline Wage & $(1)$ & $(2)$ & $(3)$ & $(4)$ \\
\hline PPS & $-0.0025^{* *}(0.0091)$ & $-0.0033^{* *}(0.0091)$ & $-0.0077 *(0.0085)$ & $-0.0087 *(0.0085)$ \\
Firm size & $0.0225^{*}(0.0137)$ & $0.0305^{* *}(0.0142)$ & $-0.0322^{* * *(0.0106)}$ & $-0.0264 * *(0.0111)$ \\
Leverage & $0.3466^{* * *}(0.0538)$ & $0.3189^{* * *(0.0529)}$ & $0.2164 * * *(0.0494)$ & $0.2031 * * *(0.0493)$ \\
Average sales & $0.3602 * * *(0.0240)$ & $0.3597 * *(0.0239)$ & $0.4483 * * *(0.0200)$ & $0.4468 * * *(0.0200)$ \\
MTB & & $-0.0106 * *(0.0029)$ & & $-0.0059 * * *(0.0028)$ \\
PCI & & & $-0.0184(0.0461)$ & $-0.0153(0.0462)$ \\
Inverse Mill's ratio & $1.2456 * *(0.6100)$ & $1.2846^{* *}(0.6031)$ & $-1.5333^{* * *(0.4087)}$ & $-1.4719 * * *(0.4100)$ \\
Intercept & $4.4954 * *(0.3286)$ & $4.3616^{* * *}(0.3991)$ & $6.0584 * *(0.3375)$ & $5.9494 * * *(0.3441)$
\end{tabular}




$\begin{array}{cllll}\text { Year Dummy } & \text { Yes } & \text { Yes } & \text { Yes } & \text { Yes } \\ \text { Industry Dummy } & \text { Yes } & \text { Yes } & \text { Yes } & \text { Yes } \\ \text { Obs. } & 2,860 & 2,860 & 2,860 & 2,860 \\ \text { Adj. } \mathrm{R}^{2} & 0.6767 & 0.6778 & 0.6794 & 0.6803\end{array}$

This table reports the coefficients and standard errors obtained from Heckman two-step analysis model of average Employee wages. In the first step, we employ a probit model of whether the firm reports the data on employee wages. The dependent variable in the first step is denoted as "pro". It is one if the employee wage data is not missing and zero otherwise. In the second step, we run an OLS regression model of employee wages. The dependent variable in the second step is the natural log of the average employee wages. All the variables in the first and second steps range from fiscal year 1992 and 2017. Numbers in the parentheses are the standard errors. *,** and *** indicate statistical significance at $10 \%, 5 \%$ and $1 \%$ level, respectively.

For the second step in Panel B, the sample contains only the firms that report staff expenses. We add the inverse Mill's ratio derived from the first step as an additional variable. In all the columns, the coefficients of PPS are significantly negative ranging from -0.0025 to -0.0087 . The coefficients of firm size, leverage and average sales per employee remain significantly positive in each column. Market-to-book ratios still have negative coefficients and significant at the $1 \%$ level in Column 2 and Column 4. In addition, the significant coefficients of the inverse Mill's ratio suggest that the inverse Mill's ratio makes contribution to making the parameters unbiased. Therefore, we support that the impacts of PPS and leverage ratios on employee wages remains negative and positive controlling for sample selection bias. As the result is consistent with those in Table 5, we support Hypothesis 1 and 2.

\subsection{Employee Wages in Technology and Non-technology Firms}

Table 7 reports the results of OLS regression in technology and non-technology firms. Examining both groups, we find that the coefficients of PPS in technology firms are negative, while they are not significant in non-technology firms. The Wald test results suggest that PPS has differential effects on employee wages in technology versus non-technology firms. Our results indicate that the influence of PPS on employee wages are more pronounced in technology firms. Graefe-Anderson et al. (2018) find that PPS provided to CEO are negative both in technology and non-technology firms. In absolute values, their results show that coefficients in non-technology firms are greater than those in technology firms. Our results are different from theirs, showing that incentive compensation to top five executives is not in line with that to CEO and implying that some executives are compensated as individuals rather than as a team.

Table 7. OLS regressions in technology and non-technology firms

\begin{tabular}{|c|c|c|c|c|c|c|c|c|}
\hline Variables & Tech & Non-Tech & Tech & Non-Tech & Tech & Non-Tech & Tech & Non-Tech \\
\hline Wage & (1) & (1) & (2) & (2) & (3) & (3) & (4) & (4) \\
\hline PPS & $\begin{array}{l}-0.0144 * * \\
(0.0067)\end{array}$ & $\begin{array}{l}-0.0136 \\
(0.0171)\end{array}$ & $\begin{array}{l}-0.0139 * * \\
(0.0067)\end{array}$ & $\begin{array}{l}-0.0138 \\
(0.0172)\end{array}$ & $\begin{array}{l}-0.0174 * * * \\
(0.0064)\end{array}$ & $\begin{array}{l}-0.0167 \\
(0.0172)\end{array}$ & $\begin{array}{l}-0.0170^{* * * *} \\
(0.0064)\end{array}$ & $\begin{array}{l}-0.0170 \\
(0.0173)\end{array}$ \\
\hline Firm size & $\begin{array}{l}0.0222 * * * \\
(0.0060)\end{array}$ & $\begin{array}{l}0.0363 * * \\
(0.0143)\end{array}$ & $\begin{array}{l}0.0256 * * * \\
(0.0061)\end{array}$ & $\begin{array}{l}0.0368 * * \\
(0.0147)\end{array}$ & $\begin{array}{l}0.0177 * * * \\
(0.0058)\end{array}$ & $\begin{array}{l}0.0339 * * \\
(0.0144)\end{array}$ & $\begin{array}{l}0.0203 * * * \\
(0.0059)\end{array}$ & $\begin{array}{l}0.0345 * * \\
(0.0148)\end{array}$ \\
\hline Leverage & $\begin{array}{l}0.2278 * * * \\
(0.0346)\end{array}$ & $\begin{array}{l}0.6548 * * * \\
(0.0920)\end{array}$ & $\begin{array}{l}0.2162^{* * *} \\
(0.0349)\end{array}$ & $\begin{array}{l}0.6514 * * * \\
(0.0942)\end{array}$ & $\begin{array}{l}0.1533 * * * \\
(0.0338)\end{array}$ & $\begin{array}{l}0.6382 * * * \\
(0.0927)\end{array}$ & $\begin{array}{l}0.1451 * * * \\
(0.0341)\end{array}$ & $\begin{array}{l}0.6345 * * * \\
(0.0950)\end{array}$ \\
\hline Average & $\begin{array}{l}0.4808^{* * * *} \\
(0.0128)\end{array}$ & $\begin{array}{l}0.3459 * * * \\
(0.0315)\end{array}$ & $\begin{array}{l}0.4785^{* * *} \\
(0.0128)\end{array}$ & $\begin{array}{l}0.3467 * * * \\
(0.0318)\end{array}$ & $\begin{array}{l}0.5111^{* * * *} \\
(0.0125)\end{array}$ & $\begin{array}{l}0.3509 * * * \\
(0.0317)\end{array}$ & $\begin{array}{l}0.5091 * * * \\
(0.0126)\end{array}$ & $\begin{array}{l}0.3517 * * * \\
(0.0320)\end{array}$ \\
\hline МТВ & & & $\begin{array}{l}-0.0052 * * * \\
(0.0020)\end{array}$ & $\begin{array}{l}-0.0001 \\
(0.0048)\end{array}$ & & & $\begin{array}{l}-0.0039 * * * \\
(0.0019)\end{array}$ & $\begin{array}{l}-0.0001 \\
(0.0047)\end{array}$ \\
\hline PCI & & & & & $\begin{array}{l}0.3120 * * * \\
(0.0238)\end{array}$ & $\begin{array}{l}-0.0738 \\
(0.0536)\end{array}$ & $\begin{array}{l}0.2994 * * * \\
(0.0239)\end{array}$ & $\begin{array}{l}-0.0739 \\
(0.0536)\end{array}$ \\
\hline Intercept & $4.0868 * * *$ & $5.7320 * * *$ & $4.0592 * * *$ & $5.7181 * * *$ & $3.5607 * * *$ & $5.8539 * * *$ & $3.5443 * * *$ & $5.8392 * * *$ \\
\hline Published & Sciedu Press & & & 253 & & \multicolumn{2}{|c|}{ ISSN 1923-4023 } & SN 1923-40 \\
\hline
\end{tabular}




\begin{tabular}{|c|c|c|c|c|c|c|c|c|}
\hline & (0.1688) & $(0.4880)$ & $(0.1689)$ & (0.4949) & $(0.1676)$ & $(0.4957)$ & (0.1677) & $(0.5023)$ \\
\hline Year & Yes & Yes & Yes & Yes & Yes & Yes & Yes & Yes \\
\hline Industry & Yes & Yes & Yes & Yes & Yes & Yes & Yes & Yes \\
\hline Obs. & 2,021 & & & 839 & 2,021 & 839 & 2,021 & 839 \\
\hline Adj. $R^{2}$ & 0.8514 & & & 0.4203 & 0.8624 & 0.4216 & 0.8627 & 0.4209 \\
\hline Chi-square & \multicolumn{2}{|c|}{10.60} & \multicolumn{2}{|c|}{10.29} & \multicolumn{2}{|c|}{17.07} & \multicolumn{2}{|r|}{16.70} \\
\hline$p$-value & \multicolumn{2}{|c|}{$(0.0011)$} & \multicolumn{2}{|c|}{ (0.0014) } & \multicolumn{2}{|c|}{$(<.0001)$} & \multicolumn{2}{|c|}{$(<.0001)$} \\
\hline
\end{tabular}

This table reports the coefficients and standard errors of the regressors in the OLS regression model of average employee wage in technology and non-technology firm, respectively. Columns with Tech show the results of technology firms, and those with Non-Tech show the results of non-technology firms. The dependent variable is the natural $\log$ of the average employee wages. PPS is the natural log of the total Pay Performance Sensitivity of the top five executives. All the variables in the sample range from fiscal year 1992 to 2017. Chi-square and $p$-value are Wald test statistics testing whether the coefficients of PPS are different between technology and non-technology firms. Numbers in the parentheses are the standard errors. *, ** and *** indicate statistical significance at $10 \% 5 \%$ and $1 \%$ level, respectively.

\subsection{Employee Wages During Different Business Cycles}

To test hypothesis 4, we present in Table 8 the results with Column "Safe" and Column "Distressed" for financially safe firms and distressed firms, respectively. We find that PPS has a negative relation to employee wages in financially safe firms, but has no significant relation in financially distressed firms. The Wald chi-square and its $p$-value indicate that there is a significant difference in the impacts of PPS on employee wages between financially safe firms and distressed firms. The results show that the impact of PPS is greater for financially safe than for distressed firms. Our results conflict with those of Graefe-Anderson et al. (2018), who show that the impacts of CEO EBC are more severe in financially distressed firms. The difference suggests that top five executives might be compensated as individuals rather than as a team.

Table 8. PPS and Employee Wages over business cycles

\begin{tabular}{|c|c|c|c|c|c|c|}
\hline Variables & Safe & Distressed & Safe & Distressed & Safe & Distressed \\
\hline Wage & (1) & (1) & (2) & (2) & (3) & (3) \\
\hline \multirow[t]{2}{*}{ PPS } & $-0.0266 * * *$ & -0.0119 & $-0.0313 * * *$ & -0.0147 & $-0.0308 * * *$ & -0.0152 \\
\hline & $(0.0083)$ & $(0.0145)$ & $(0.0083)$ & $(0.0144)$ & $(0.0083)$ & $(0.0144)$ \\
\hline \multirow[t]{2}{*}{ Firm size } & $0.0451 * * *$ & 0.0092 & $0.0409 * * *$ & 0.0120 & $0.0436 * * *$ & 0.0153 \\
\hline & $(0.0080)$ & $(0.0140)$ & $(0.0077)$ & $(0.0138)$ & $(0.0079)$ & $(0.0140)$ \\
\hline \multirow[t]{2}{*}{ Leverage } & 0.1287 & $0.2940 * * *$ & 0.0345 & $0.2888 * * *$ & 0.0259 & $0.2763 * * *$ \\
\hline & $(0.0911)$ & $(0.0591)$ & $(0.0923)$ & $(0.0579)$ & $(0.0925)$ & $(0.0589)$ \\
\hline \multirow[t]{2}{*}{ Average sales } & $0.4630 * * *$ & $0.3455^{* * *}$ & $0.4811 * * *$ & $0.3490 * * *$ & $0.4810 * * *$ & $0.3486 * * *$ \\
\hline & $(0.0157)$ & $(0.0255)$ & $(0.0159)$ & $(0.0253)$ & $(0.0159)$ & $(0.0253)$ \\
\hline \multirow[t]{2}{*}{ MTB } & $-0.0038^{*}$ & -0.0070 & & & $-0.0034 * * *$ & -0.0056 \\
\hline & $(0.0023)$ & $(0.0047)$ & & & $(0.0023)$ & $(0.0047)$ \\
\hline \multirow[t]{2}{*}{ PCI } & & & $0.1725^{* * *}$ & $0.1592 * * *$ & $0.1709 * * *$ & $0.1545^{* * *}$ \\
\hline & & & $(0.0326)$ & $(0.0448)$ & $(0.0326)$ & $(0.0449)$ \\
\hline \multirow[t]{2}{*}{ Intercept } & $3.9087 * * *$ & $5.8295 * * *$ & $3.6606^{* * *}$ & $5.5812 * * *$ & $3.6188 * * *$ & $5.5442 * * *$ \\
\hline & $(0.2179)$ & $(0.3432)$ & $(0.2214)$ & $(0.3492)$ & $(0.2231)$ & $(0.3505)$ \\
\hline Year Dummy & Yes & Yes & Yes & Yes & Yes & Yes \\
\hline Industry Dummy & Yes & Yes & Yes & Yes & Yes & Yes \\
\hline
\end{tabular}




\begin{tabular}{|c|c|c|c|c|c|c|}
\hline Obj. & 1,662 & 728 & 1,662 & 728 & 1,662 & 728 \\
\hline Adj. $R^{2}$ & 0.8023 & 0.7487 & 0.8054 & 0.7525 & 0.8055 & 0.7526 \\
\hline Chi-square & \multicolumn{2}{|c|}{14.40} & \multicolumn{2}{|r|}{19.90} & \multicolumn{2}{|r|}{21.20} \\
\hline$p$-value & \multicolumn{2}{|c|}{$(0.0002)$} & \multicolumn{2}{|r|}{$(<.0001)$} & \multicolumn{2}{|r|}{$(<.0001)$} \\
\hline
\end{tabular}

This table reports the coefficients and standard errors of the regressors in the OLS regression model of average employee wage within different business cycles. Columns "Safe" show the results of financially safe firms, and Columns "Distressed" report the results of financially distressed firms. The dependent variable is the natural $\log$ of the average employee wages. PPS is the natural log of the total Pay Performance Sensitivity of the top five executives. All the variables in data sample range from fiscal year 1992 to 2017. Chi-square and $p$-value are Wald test statistics indicating whether the coefficients of PPS are different between firms in different financial states. Numbers in the parentheses are the standard errors. *, ** and *** indicate statistical significance at $10 \% 5 \%$ and $1 \%$ level, respectively.

\subsection{Robustness Tests}

Table 9 presents results from the two-stage model. In Panel A for the first stage, we find that the marginal tax rates have significantly positive coefficients as in $0.43-0.53$, which are consistent with Chemmanur et al. (2013). The partial F-statistics of marginal tax rates falls in $28.30-29.27$, respectively. Stock et al. (2002) suggest that the critical F-value is 8.96 when the number of instruments is one. The instrument is considered to be strong if the first-stage partial F-statistic is above the critical value. The results suggest that the marginal tax rate is a strong instrumental variable. Panel B presents results from the second stage. We employ the fitted value of leverage as an independent variable. The results show that PPS coefficients maintain significantly negative, which is consistent with those in Table 5. The coefficients of leverage become negative after controlling for the potential endogeneity concern. Furthermore, the coefficients of firm size and average sales remain significantly positive as they are in Table 5 . Hence, when we control for the potential endogeneity concern, executive incentive compensation maintains negative impacts on employee wages.

Table 9. Instrumental variable regressions of employee wages: Two-stage least square regression analysis

Panel A: First stage--Leverage is the dependent variable.

\begin{tabular}{|c|c|c|c|c|}
\hline Leverage & $(1)$ & $(2)$ & (3) & $(4)$ \\
\hline PPS & $-0.0381 * * *(0.0035)$ & $-0.0382 * * *(0.0034)$ & $-0.0368 * * *(0.0034)$ & $-0.0369 * * *(0.0034)$ \\
\hline MTR & $0.5373 * * *(0.0999)$ & $0.4414 * * *(0.1010)$ & $0.5250 * * *(0.0992)$ & $0.4324 * * *(0.1003)$ \\
\hline Firm size & $0.0043(0.0032)$ & $0.0085^{* * *}(0.0032)$ & $0.0034(0.0031)$ & $0.0075 * *(0.0032)$ \\
\hline Average sales & $0.0153 * * *(0.0046)$ & $0.0131 * * *(0.0046)$ & $0.0193 * * *(0.0046)$ & $0.0170 * * *(0.0046)$ \\
\hline MTB & & $-0.0058 * * *(0.0011)$ & & $-0.0056 * * *(0.0011)$ \\
\hline PCI & & & $0.0585 * * *(0.0093)$ & $0.0572 * * *(0.0093)$ \\
\hline EBIT/AT & $-1.1375^{* * *}(0.0573)$ & $-1.0507 * * *(0.0578)$ & $-1.1215 * * *(0.0554)$ & $-1.0378 * * *(0.0575)$ \\
\hline Std. (EBIT/AT) & $-0.0321(0.0253)$ & $-0.0282(0.0251)$ & $-0.0284(0.0251)$ & $-0.0246(0.0250)$ \\
\hline Intercept & $0.4221 * * *(0.0692)$ & $0.4030 * * *(0.0690)$ & $0.3355 * * *(0.0700)$ & $0.3189 * * *(0.0698)$ \\
\hline Year Dummy & Yes & Yes & Yes & Yes \\
\hline Industry Dummy & No & No & No & No \\
\hline Obs. & 2,691 & 2,691 & 2,691 & 2,691 \\
\hline Adj. $\mathrm{R}^{2}$ & 0.2334 & 0.2413 & 0.2443 & 0.2516 \\
\hline Partial F-test of MTR F-statistic & 28.30 & 28.59 & 29.06 & 29.27 \\
\hline$p$-value of partial F-test & $<.0001$ & $<.0001$ & $<.0001$ & $<.0001$ \\
\hline
\end{tabular}




\begin{tabular}{cllll}
\hline \multicolumn{6}{c}{ Panel B: Second stage--Average Employee Wage is the dependent variable. } & & \\
\hline Wage & $(1)$ & $(2)$ & $(3)$ & $(4)$ \\
\hline PPS & $-0.0353^{*}(0.0215)$ & $-0.0542^{*}(0.0279)$ & $-0.0367^{*}(0.0208)$ & $-0.0557^{* *}(0.0271)$ \\
Leverage & $-1.1691^{* *}(0.5109)$ & $-1.6581^{* *}(0.6848)$ & $-1.0867^{* *}(0.5098)$ & $-1.5925^{* *}(0.6849)$ \\
Firm size & $0.0346^{* * *}(0.0093)$ & $0.0482^{* * *}(0.0123)$ & $0.0378^{* * *}(0.0089)$ & $0.0511^{* * *}(0.0117)$ \\
Average sales & $0.5965^{* * *}(0.0146)$ & $0.5979^{* * *}(0.0151)$ & $0.5809^{* * *}(0.0156)$ & $0.5842^{* * *}(0.0175)$ \\
MTB & & $-0.0158^{* * *}(0.0055)$ & & $-0.0160^{* * *}(0.0054)$ \\
PCI & & & $-0.2113^{* * *}(0.0394)$ & $-0.1855^{* * *}(0.0481)$ \\
EBIT/AT & $-3.0765^{* * *}(0.5382)$ & $-3.3948^{* * *}(0.6639)$ & $-3.0406^{* * *}(0.5296)$ & $-3.3678^{* * *}(0.6561)$ \\
Std. (EBIT/AT) & $-0.0578(0.0721)$ & $-0.0627(0.0785)$ & $-0.0687(0.0699)$ & $-0.0723(0.0764)$ \\
Intercept & $3.9871^{* * *}(0.3227)$ & $4.1410^{* * *}(0.3834)$ & $4.2650^{* * *}(0.2852)$ & $4.3872^{* * *}(0.3345)$ \\
Year Dummy & Yes & Yes & Yes & Yes \\
Industry Dummy & No & No & No & No \\
Obs. & 2,519 & 2,519 & 2,519 & 2,519 \\
Adj. $\mathrm{R}^{2}$ & 0.5383 & 0.4981 & 0.5597 & 0.5173
\end{tabular}

This table reports the coefficients and standard errors obtained from 2LSL robustness test. In the first stage, we use marginal tax rate based on income before interest expense has been deducted (MTRB) as the instrumental variable. And the dependent variable is leverage which is measured as market leverage. In the second stage, we include the fitted value of leverage derived from the first stage as an independent variable. The dependent variable is the natural $\log$ of average employee wages. The data for the variables in the first and second stages range from fiscal year 1992 and 2017. Numbers in the parentheses are the standard errors. *, ** and *** indicate statistical significance at $10 \%, 5 \%$ and $1 \%$, respectively.

Table 10 reports results from an alternate variable method for robustness of our findings. We use excess returns as an alternate measure for executives' performance and add an interaction term between PPS and excess returns. We find that the coefficients of excess returns are all non-significant in all the columns. When we add PPS in Column 4, the coefficient of PPS becomes significantly negative. Furthermore, the product term of PPS and excess returns carry insignificant coefficients. It suggests that PPS cannot be replaced by excess returns as a proxy for incentive compensation to executives in our study.

Table 10. Interaction effect of PPS and excess return in the OLS regressions of employee wages

\begin{tabular}{|c|c|c|c|c|}
\hline Wage & (1) & (2) & (3) & (1) \\
\hline \multirow[t]{2}{*}{ PPS } & & & & $-0.0137^{*}$ \\
\hline & & & & $(0.0083)$ \\
\hline \multirow[t]{2}{*}{ Firm size } & $0.0192 * * *$ & $0.0230 * * *$ & $0.0187 * * *$ & $0.0310 * * *$ \\
\hline & $(0.0049)$ & $(0.0050)$ & $(0.0048)$ & $(0.0059)$ \\
\hline \multirow[t]{2}{*}{ Leverage } & $0.3192 * * *$ & $0.3059 * * *$ & $0.2958 * * *$ & $0.2623^{* * *}$ \\
\hline & $(0.0347)$ & $(0.0350)$ & $(0.0345)$ & $(0.0356)$ \\
\hline \multirow[t]{2}{*}{ Average sales } & $0.4549 * * *$ & $0.4542 * * *$ & $0.4670 * * *$ & $0.4677 * * *$ \\
\hline & $(0.0125)$ & $(0.0125)$ & $(0.0125)$ & $(0.0125)$ \\
\hline \multirow[t]{2}{*}{ MTB } & & $-0.0056^{* * *}$ & & $-0.0053^{* * *}$ \\
\hline & & $(0.0020)$ & & $(0.0019)$ \\
\hline \multirow[t]{2}{*}{ PCI } & & & $0.1687 * * *$ & $0.1691 * * *$ \\
\hline & & & $(0.0231)$ & $(0.0231)$ \\
\hline
\end{tabular}


Excess return

0.0419

(0.2167)

0.1057

(0.2176)

0.0233

$-0.1272$

PS $\times$ Excess return

Intercept

$4.2125 * * *$

$4.1700 * * *$

(0.1608)

(0.1603)

Yes

Year Dummy

Yes

Industry Dummy

Yes

2,829

0.7809

Adj. $\mathrm{R}^{2}$

This table reports the coefficients and standard errors of the regressors in the OLS regression model of average employee wages with examining the robustness of PPS using excess return as alternate variable. The dependent variable is the natural log the average employee wages; PPS is the natural log of the total Pay Performance Sensitivity of the top five executives. We add a cross product term of PPS and excess return, which can capture the interaction effect of the two variables. All the variables in the data sample range from the fiscal year 1992 to 2017. Numbers in the parentheses are the standard errors. * ** and *** indicate statistical significance at $10 \%, 5 \%$ and $1 \%$ level, respectively.

In summary, we find that the incentive compensation to top five executives is in line with that of CEO in suppressing employee wages, but the way how they are compensated differs from that of CEO by firm characteristics such as technology firms and financially safe firms. While it appears that top five executives are compensated as a team on average, they seem to be compensated as isolated individuals in various firm characteristics. The debate on whether top executives are compensated as a team or isolated individuals in the literature seems to be on the principle that they are mutually exclusive. However, our results suggest that the debate does not have to be on the mutually exclusiveness. Top executives can be compensated as a team or as individuals with different firm characteristics.

\section{Conclusion}

Conducting multiple regressions to examine the impacts of executive EBC on employee wages, we find that a negative relation between employee wages and executive compensation is statistically significant. When executives are granted more equity-based compensation, employees receive lower wages, which might lead to a lower productivity and less profit. However, shareholders' initial purpose of increasing equity-based compensation is to motivate executives to increase firm performance. Therefore, it appears that the strategy of granting more EBC to executives might worsen the income inequality between executives and employees by suppressing employee wages and deteriorate firm performance in the long run.

We show that executive EBC has greater negative impacts on employee wages in technology firms than in non-technology firms. The reason may be that employees are more entrenched in technology firms, and managers in those firms show less concern on losing their employees, contradicted to Berk et al. (2010). Therefore, in technology firms, executives are more likely to suppress employee wages to increase their own benefits. On the other hand, negative impacts of executive compensation on employee wages for firms in good financial states are stronger than those in weak financial states. In financially distressed firms, managers eagerly want to increase employee productivity to bring back firms into financially safe states. Hence, the executives are less likely to suppress their employee wages in financially distressed firms.

This study contributes to the literature by investigating how equity-based compensation to top five executives affects employee wage and whether top executives are compensated as a team or individuals. Our results suggest that incentive compensation to executives tends to suppress employee wages as that to CEO. While top executives are compensated as a team on average, they appear to be compensated as isolated individuals with different firm characteristics.

We recognize weaknesses in our study and offer directions on future research. The current study does not consider potential impacts of corporate governance and CEO pay slice (CPS) on executive compensation and employee wages. 
Enhanced corporate governance might not suppress employee wages to preserve employee motivation. CPS is measured by a fraction of CEO compensation to total compensation of top-five executives and reflects CEO power in a firm. Powerful CEO might preserve employee wages in the existence of strong incentive compensation. Adding corporate governance and CPS in future research will help researchers better understand the impacts of executive compensation on employee wages.

\section{References}

Altman, E. I. (1968). Financial ratios, discriminant analysis and the prediction of corporate bankruptcy. Journal of Finance, 23(4), 589-609. https://doi.org/10.1111/j.1540-6261.1968.tb00843.x

Baum, C. L., Ford, W. F., \& Zhao, K. M. (2012). Top five executives' share of core earnings. Journal of Financial and Economic Practice, 12(2), 103-115.

Berk, J. B., Stanton, R., \& Zechner, J. (2010). Human capital, bankruptcy, and capital structure. The Journal of Finance, 65(3), 891-926. https://doi.org/10.1111/j.1540-6261.2010.01556.x

Bertrand, M., \& Mullainathan, S. (2003). Enjoying the quiet life? Corporate governance and managerial preferences. Journal of Political Economy, 111(5), 1043-1075. https://doi.org/10.1086/376950

Black, F., \& Scholes, M. (1973). The pricing of options and corporate liabilities. The Journal of Political Economy, 81(3), 637-654. https://doi.org/10.1086/260062

Brown, C., \& Medoff, J. (1989). The Employer Size-Wage Effect. The Journal of Political Economy, 97, 1027-1059. https://doi.org/10.1086/261642

Chemmanur, T. J., Cheng, Y., \& Zhang, T. (2013). Human capital, capital structure, and employee pay: An empirical analysis. Journal of Financial Economics, 110(2), 478-502. https://doi.org/10.1016/j.jfineco.2013.07.003

Coles, J. L., Daniel, N. D., \& Naveen, L. (2006). Managerial incentives and risk-taking. Journal of Financial Economics, 79(2), 431-468. https://doi.org/10.1016/j.jfineco.2004.09.004

Core, J., \& Guay, W. (2002). Estimating the value of employee stock option portfolios and their sensitivities to price and volatility. Journal of Accounting Research, 40(3), 613-630. https://doi.org/10.1111/1475-679X.00064

Fama, E. F. (1980). Agency Problems and the Theory of the Firm. The Journal of Political Economy, 88(2), 288-307. https://doi.org/10.1086/260866

Givoly, D., Hayn, C., Ofer, A. R., \& Sarig, O. (1992). Taxes and capital structure: Evidence from firms' response to the Tax Reform Act of 1986. Review of Financial Studies, 5(2), 331-355. https://doi.org/10.1093/rfs/5.2.331

Graefe-Anderson, R., Pyo, U., \& Zhu, B. (2018). Does CEO compensation suppress employee wages?. Review of Accounting \& Finance, 17(4), 426-452. https://doi.org/10.1108/RAF-04-2017-0065

Harris, M., \& Raviv, A. (1991). The theory of capital structure. Journal of Finance, 46(1), 297-355. https://doi.org/10.1111/j.1540-6261.1991.tb03753.x

Heckman, J. J. (1979). Sample selection bias as a specification error. Econometrica, 47(1), 153-161. https://doi.org/10.2307/1912352

Hermalin, B. E., \& Weisbach, M. S. (1991). The effects of board composition and direct incentives on firm performance. Financial Management, 20(4), 101-112. https://doi.org/10.2307/3665716

Jensen, M. C. (1986). Agency cost of free cash flow, corporate finance, and takeovers. American Economic Review, $76(2)$.

Jensen, M. C., \& Meckling, W. H. (1976). Theory of the firm: Managerial behavior, agency costs and ownership structure. Journal of Financial Economics, 3(4), 305-360. https://doi.org/10.1016/0304-405X(76)90026-X

Jensen, M. C., \& Murphy, K. J. (1990). Performance pay and top-management incentives. Journal of Political Economy, 98(2), 225-264. https://doi.org/10.1086/261677

Kaplan, S. N. (2012). Executive compensation and corporate governance in the US: perceptions, facts and challenges. National Bureau of Economic Research. No. w18395. https://doi.org/10.3386/w18395

Kong, X. (2017). Relationship between CEO Pay Slice and firm performance. Working Paper. SSRN. https://doi.org/10.2139/ssrn.2957769

Leary, M., \& Roberts, M. (2010). The pecking order, debt capacity, and information asymmetry. Journal of Financial Economics, 95, 332-355. https://doi.org/10.1016/j.jfineco.2009.10.009 
Li, C. (2018). Are Top Management Teams Compensated as Teams? A Structural Modeling Approach. Baruch College Zicklin School of Business Research Paper No. 2018-02-02. https://doi.org/10.2139/ssrn.2520188

Merton, R. C. (1973). Theory of rational option pricing. The Bell Journal of Economics and Management Science, 4(1), 141-183. https://doi.org/10.2307/3003143

Morck, R., Shleifer, A., \& Vishny, R. W. (1988). Management ownership and market valuation: An empirical analysis. Journal of Financial Economics, 20, 293-315. https://doi.org/10.1016/0304-405X(88)90048-7

Murphy, K. J. (1985). Corporate performance and managerial remuneration: An empirical analysis. Journal of Accounting and Economics, 7(1), 11-42. https://doi.org/10.1016/0165-4101(85)90026-6

Murphy, K. J. (1999). Executive compensation. Handbook of Labor Economics, 3, 2485-2563. https://doi.org/10.1016/S1573-4463(99)30024-9

Murphy, K. J. (2012). Executive compensation: Where we are, and how we got there. Working Paper, SSRN. https://doi.org/10.2139/ssrn.2041679

Pagano, M., \& Volpin, P. F. (2005). Managers, workers, and corporate control. The Journal of Finance, 60(2), 841-868. https://doi.org/10.1111/j.1540-6261.2005.00748.x

Parsons, C., \& Titman, S. (2009). Empirical capital structure: A review. Foundations and Trends in Finance, 3, 1-93. https://doi.org/10.1561/0500000018

Stock, J., Wright, J., \& Yogo, M. (2002). A survey of weak instruments and weak identification in generalized method of moments. Journal of Business and Economics Statistics, 20, 518-529. https://doi.org/10.1198/073500102288618658

Tobin, J. (1958). Estimation of relationships for limited dependent variables. Econometrica, 26, 24-36. https://doi.org/10.2307/1907382

Wooldridge, J. (2002). Econometric Analysis of Cross Section and Panel Data. MIT Press, Cambridge, MA.

\section{Note}

Note 1. Following Chemmanur et al. (2013), technology firms are those with primary SIC codes: 3570, 3571, 3572, 3576, 3577, 3661, 3674, 4812, 4813, 5045, 5961, 7370, 7372 and 7373. Non-technology firms include those firms with SIC codes less than 4000 and are not included as technology firms.

\section{Copyrights}

Copyright for this article is retained by the author(s), with first publication rights granted to the journal.

This is an open-access article distributed under the terms and conditions of the Creative Commons Attribution license (http://creativecommons.org/licenses/by/4.0/). 